\title{
CLINICOPATHOLOGICAL STUDY OF CHANGE OF VOICE
}

\author{
ARIFUZZAMAN $\mathrm{M}^{1}$, FATTAH $\mathrm{SN}^{2}$, ISLAM MN ${ }^{3}$, HASAN MM ${ }^{4}$, ISLAM MM ${ }^{5}$, TABASSUM CT ${ }^{6}$, \\ MONIRA S ${ }^{7}$, TANVIR SM ${ }^{8}$, FARHAD M ${ }^{9}$
}

\begin{abstract}
Background: Change of voice is one of the common complaints in ENT practice and hoarseness of voice is the commonest symptom of changed voice quality. Hoarseness is invariably the earliest manifestation of conditions directly or indirectly affecting the voice apparatus. Though most common causes of hoarseness are benign and vocal abuse is the commonest among them, but we should always investigate for more sinister pathology like malignancy.
\end{abstract}

Objectives: To find out the symptoms, signs and pathological incidence, leading to change of voice for early diagnosis and interventional purpose.

Methods: Total 87 patients of change of voice, studied in 06 months duration from $1^{\text {st }}$ January 2016 to $30^{\text {th }}$ June 2016 in the Department of ENT \& Head-Neck Surgery, Dhaka Medical College Hospital, Dhaka. The cases were selected according to the eligibility criteria by purposive sampling. Then the data were collected by the active participation of the patients interviewed by the preformed proforma of data collection sheet.

Results: Maximum number of cases of change of voice were due to carcinoma larynx (37.93\%), then chronic laryngitis (20.99\%), followed by vocal cord nodules (19.54\%) and vocal cord polyps (8.05\%.). Laryngopharyngeal reflux was found in $45.95 \%$ patients of chronic laryngitis. Males were affected more than females (1.81:1). Most of the patients were in the age group of 21 to 50 years. Peak incidence was in the 4th decade. Labourers/ daily wage earners formed the predominant group. Majority of patients were from low socioeconomic class. Smoking, vocal abuse, smoking and infections were the common predisposing factors.

Conclusion: Hoarseness of voice is just a symptom with a very diverse etiology. The etiological data varies in different geographical location and from one center to other, so every case should be carefully and thoroughly evaluated to know the diagnosis and underlying pathology for early and prompt management.

Keywords: Change of voice, hoarseness of voice, laryngeal carcinoma, vocal cord nodule, vocal abuse.

\section{Introduction}

Change of voice can be defined as abnormal production of sound, perceived as hoarseness, raspiness, breathiness, harshness and low pitched voice. Proper knowledge of symptoms, signs \& common causes are important for early diagnosis. We then take immediate necessary intervention to bring the patient's voice back. Usually change of voice is a term, which is used to describe a change in quality of voice ranging from voice harshness to voice weakness. ${ }^{1}$ There are three phases in speech. The pulmonary phase creates the energy flow with inflation and expulsion of air. This activity provides the larynx

1. Dr. Md. Arifuzzaman, Specialist, Department of ENT \& Head-Neck Surgery, Square Hospitals Ltd. Dhaka.

2. Dr. Shaikh Nurul Fattah, Professor \& Head, Department of ENT \& Head-Neck Surgery, Dhaka Medical College Hospital, Dhaka.

3. Dr. Mohammad Nazrul Islam, Registrar, Department of ENT \& Head \& Neck Surgery, Sir Salimullah Medical College \& Mitford Hospital, Dhaka

4. Dr. Md. Mehedi Hasan, Specialist, Department of ENT \& Head-Neck Surgery, Square Hospitals Ltd. Dhaka

5. Dr. Md. Monirul Islam, Assistant Surgeon, 250 bedded general Hospital, Pabna.

6. Dr. Chowdhury Tamanna Tabassum, Specialist, Department of Medicine, Square Hospitals Ltd. Dhaka

7. Dr. Shirajum Monira, Clinical Pathologist, Department of Medicine, Dhaka Medical College

8. Dr. Sardar Mohammad Tanvir, OSD Dhaka Medical College, Dhaka

9. Dr. Mohammad Farhad, Medical Officer, DG Office, Dhaka

Correspondence: Dr. Md. Arifuzzaman, Specialist, Department of ENT \& Head-Neck Surgery, Square hospitals Ltd.

Dhaka. E-mail: drarifuzzamanbappi@gmail.com Mobile: +8801717078496

Received: 26-04-2020

Revision: 01-06-2020

Accepted: $21-10-2020$ 
with a column of air for the laryngeal phase, in which vocal cords vibrate at certain frequencies to create sound that is unique to every individual. The oral phase occurs in the oral cavity where sound is modified and words are formed by the action of the pharynx, tongue, lips and teeth. Dysfunction in any of these can lead to voice changes. Disorders originating in either the lungs or oral cavity are not considered to be true hoarseness. True hoarseness from a laryngeal origin usually results in rough raspy voice. $^{1}$

Voice is an auditory perceptual term that means the audible sound produced by the larynx, which has such parameters as pitch, loudness, quality and variability. ${ }^{2}$ In summary, change of voice is the abnormal quality of voice that is rough, harsh and has lower pitch than normal for the individual. ${ }^{3}$ Hoarseness of voice is a symptom, not a diagnosis and therefore requires a careful determination of the underlying cause in every case. ${ }^{4}$ Hoarseness can be divided into acute and chronic onset. Acute hoarseness persists up to 2 weeks, more than 2 weeks of hoarseness can be termed as chronic. ${ }^{5}$

Change of voice may be a feature of laryngeal obstruction or airway obstruction. Usually occurs in Infections, such as acute epiglottitis, diphtheria, croup, laryngeal abscess or oedema caused by airway burns, anaphylaxis, physical trauma and angio oedema.

Innervation of the laryngeal muscles are from the vagus nerve via its branches, superior laryngeal and recurrent laryngeal nerves. The recurrent laryngeal nerve controls abduction and adduction of the vocal cords. It has a long course, from the base of the skull to the mediastinum, on the left side it loops under the aortic arch and on the right under the subclavian artery. ${ }^{6}$ Vocal cord immobility most often caused by laryngeal nerve palsy or crico arytenoid joint disease. ${ }^{7}$ Laryngeal nerve palsy has various causes, including lung cancer, thoracic aortic aneurysm, stroke and other focal brain lesions. In Parkinson's disease, Myasthenia gravis \& motor neurone disease, voice change is a presenting feature. ${ }^{8}$ Hypothyroidism, acromegaly, rheumatoid arthritis affecting the cricoarytenoid joints causes change of voice. Granulomatous diseases like sarcoidosis, tuberculosis, syphilis, Wegener's granulomatosis \& autoimmune disorders can also affect the larynx and thereby precipitate change of voice. ${ }^{8,9}$ Congenital causes of change of voice in children are laryngeal web, laryngomalacia, laryngeal papillomas, congenital cyst, vocal cord nodules, and very rarely, malignancy. ${ }^{10}$

Voice quality can be evaluated using the GRBAS (Grade, Roughness, Breathy voice, Asthenia and Strain) assessment. ${ }^{11}$ ENT assessment should be include Inspection of the larynx by indirect laryngoscopy and fibreoptic laryngoscopy. Management depends on the specific cause, but voice therapy and other non-surgical management is the first line treatment for most benign lesions of the larynx. ${ }^{12}$

Non-surgical management includes voice hygiene advice like adequate hydration, avoidance of vocal strain (shouting, throat clearing, excessive voice use), smoking cessation, alcohol reduction and by treating gastro-oesophageal reflux. Voice therapy techniques can be use to maximize vocal effectiveness. ${ }^{13}$ On the other hand, laryngeal papillomas require surgery first-line. Persistent nodules and polyps also require surgery. Various surgical techniques are used now a days to treat vocal cord paralysis. ${ }^{14}$

Voice therapy is often used as a adjunct to surgery. Any growth in glottis, supra glottis, pyriform fossa requires direct laryngoscopic excision or biopsy followed by histopathological examination. Tracheostomy is sometimes needed to relieve breathlessness due to mechanical effect of growth or tumor in larynx. ${ }^{15}$

This study will focus on the clinicopathological profile by evaluating age, sex, duration, symptoms, etiology and histopathological incidence, leading to change of voice for early diagnosis and intervention.

\section{Materials and Methods}

This is a cross-sectional study which was conducted in the Department of ENT and Head Neck Surgery, Dhaka Medical College Hospital,Dhaka with a sample size of 87 from 
January' 2016 to June'2016 . All patients undergoing direct laryngoscopy or/and fibre optic laryngoscopy in the Department of ENT and Head Neck Surgery in Dhaka Medical College Hospital were included in the study. Patients were randomly enrolled matching the inclusion and exclusion criteria.

\section{Results}

\section{Table-I}

Age distribution of the study population with change of voice $(n=87)$

\begin{tabular}{lcc}
\hline $\begin{array}{c}\text { Age group } \\
\text { (Years) }\end{array}$ & $\begin{array}{c}\text { Study } \\
\text { patients }\end{array}$ & $\begin{array}{c}\text { Percentage } \\
(\%)\end{array}$ \\
\hline $0-10$ & 03 & $3.44 \%$ \\
$11-20$ & 07 & $8.05 \%$ \\
$21-30$ & 13 & $14.94 \%$ \\
$31-40$ & 25 & $28.74 \%$ \\
$41-50$ & 11 & $12.64 \%$ \\
$51-60$ & 18 & $20.69 \%$ \\
$>60$ & 10 & $11.49 \%$ \\
\hline Total & 87 & $100 \%$ \\
\hline
\end{tabular}

Most of the patients are in the age group of 3140 years $(28.74 \%)$ and then in the age group of 51-60 years (20.69\%)

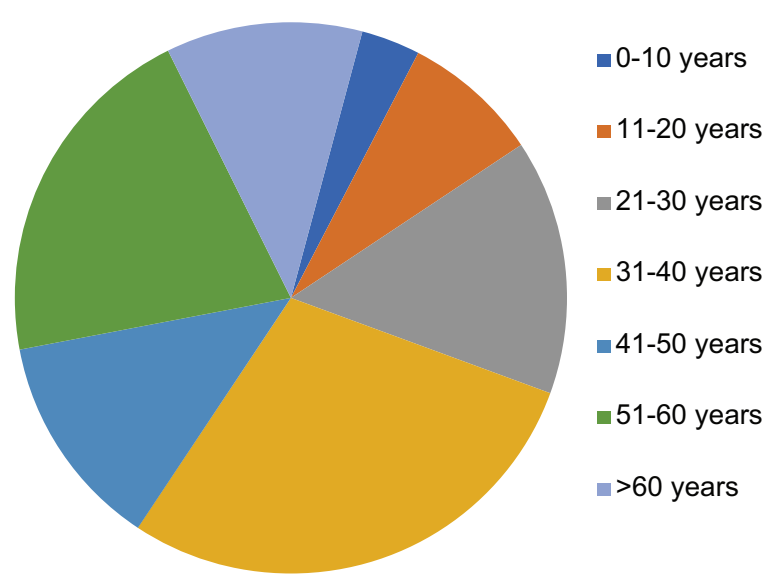

Figure shows age distribution of study population with change of voice

\section{Table-II}

Sex distribution of the study population with change of voice $(n=87)$

\begin{tabular}{lcc}
\hline Gender & No of patients & Percentage $\%$ \\
\hline Male & 56 & $64.37 \%$ \\
Female & 31 & $35.63 \%$ \\
Total & 87 & $100 \%$ \\
\hline
\end{tabular}

Male patient are more than female with male female ratio 1.81: 1 .

Table III

Occupation/Nature of work causing change of voice according to Koufman and Isaacson classification ${ }^{17}$ in study population $(n=87)$

\begin{tabular}{|c|c|c|c|}
\hline Koufman Classification level & Occupation/Nature of work & Study & Percentae (\%) \\
\hline & & atients $n$ & \\
\hline Level IElite vocal performers & - $\quad$ Singers $(n=1)$ & 2 & $2.30 \%$ \\
\hline & - Actors $(\mathrm{n}=1)$ & & \\
\hline Level IIProfessional voice users & - Political leader $(n=2)$ & 8 & $9.19 \%$ \\
\hline & . Teachers $(n=5)$ & & \\
\hline & - Telephone operator $(n=1)$ & & \\
\hline Level IIINon vocal professionals & - Lawyers $(\mathrm{n}=1)$ & 1 & $1.15 \%$ \\
\hline Level IVNon vocal non professionals & - Labourers/Daily wage & 76 & $87.35 \%$ \\
\hline & earners $(n=22)$ & & \\
\hline & - Housewife $(n=21)$ & & \\
\hline & - Businessman $(n=11)$ & & \\
\hline & - Clerks $(n=4)$ & & \\
\hline & - Canvasser $(n=18)$ & & \\
\hline & Total & 87 & $100 \%$ \\
\hline
\end{tabular}


Figure shows sex distribution of study population with change of voice.

In this study we found $2.30 \%$ elite vocal performers, 1 of them was singer $\& 1$ was Actor. $9.19 \%$ professional voice users. Among them 2 person were political leaders, 5 were teachers and 1 person was telephone operator by profession. $1.15 \%$ non-vocal professionals, only 1 person was lawyer. $87.35 \%$ non-vocal nonprofessionals, among them daily labourers or daily wage earners were 22 in number, 21 were housewives, 11 were businessmans, 4 were clerks and 18 were canvassers.

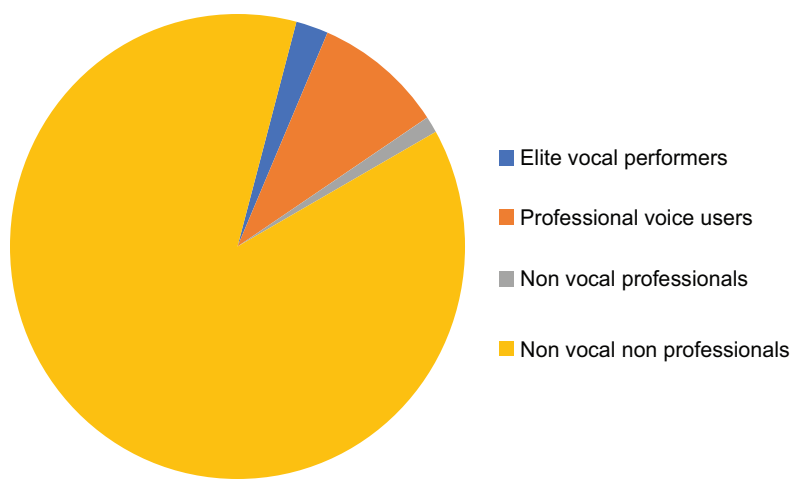

Figure shows Occupation/Nature of work causing change of voice according to Koufman and Isaacson classification in study population.

Table IV

Relation of smoking \& Change of voice in study population $(n=87)$

\begin{tabular}{lcc}
\hline Habit & No of patient & Percentage $\%$ \\
\hline Smoker & 38 & $43.68 \%$ \\
Non smoker & 49 & $56.32 \%$ \\
\hline Total & 87 & $100 \%$ \\
\hline
\end{tabular}

A large number of patients had habit of cigarette smoking. 38 patients out of total 87 patients with change of voice were smoker $(43.68 \%)$. So, it is the most pre disposing factor for hoarseness.

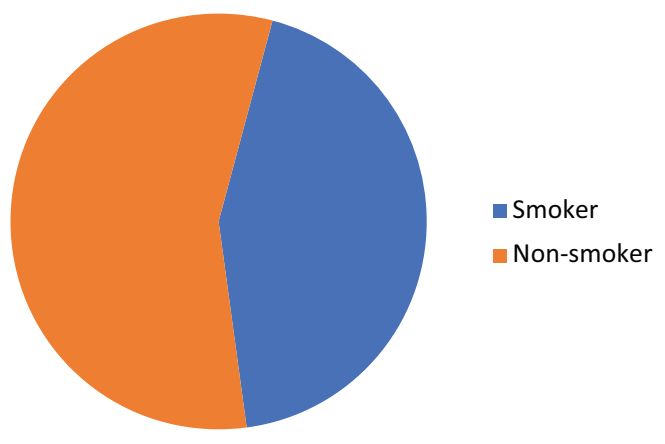

Figure shows relation of smoking $\&$ change of voice in study population.

Table-V

Clinical presentation of study population $(n=87)$

\begin{tabular}{lcc}
\hline Presentation & No of cases & Percentage \% \\
\hline Change of voice & 87 & $100 \%$ \\
Vocal fatigue & 32 & $36.78 \%$ \\
Irritative cough & 26 & $29.88 \%$ \\
Sore throat & 16 & $18.39 \%$ \\
Breathy voice & 17 & $19.54 \%$ \\
Cold / URTI & 14 & $16.09 \%$ \\
Difficulty in swallowing & 10 & $11.49 \%$ \\
Weight loss & 09 & $10.34 \%$ \\
Neck swelling & 06 & $6.89 \%$ \\
Haemoptysis & 02 & $2.29 \%$ \\
Respiratory distress & 03 & $3.45 \%$ \\
Heart burn & 01 & $1.15 \%$ \\
Vomiting & 02 & $2.29 \%$ \\
\hline
\end{tabular}

Apart from the symptom of change in voice (100 $\%)$. Other common presentations were vocal fatigue (36.78\%), Irritative cough (29.88\%), sore throat (18.39\%), Breathy voice (19.54\%) and common cold or upper respiratory tract infection $(16.09 \%)$ in descending order of frequency. Among the patients of laryngeal carcinoma 06 cases had palpable neck node, difficulty in swallowing was present in 10 cases and respiratory distress was present in 03 cases who were suffering from advanced carcinoma. 
Table VI

Causes of change of voice in study population $(n=87)$

\begin{tabular}{lcc}
\hline Disease / Causes & No of patients & Percentage \% \\
\hline Chronic laryngitis & 20 & $22.99 \%$ \\
Ca larynx : & & \\
· Suraglottic $(\mathrm{n}=28)$ & & \\
· Glottic $(\mathrm{n}=4)$ & 33 & $37.93 \%$ \\
· Subglottic(n=1) & 03 & $3.45 \%$ \\
Ca thyroid & 07 & $8.05 \%$ \\
Vocal cord polyp & 17 & $19.54 \%$ \\
Vocal cord nodule & 01 & $1.15 \%$ \\
Subglottic stenosis & 01 & $1.15 \%$ \\
Recurrent laryngeal papillomatosis & 01 & $1.15 \%$ \\
Post Thyroidectomy & 01 & $1.15 \%$ \\
Exuberant granulation tissue & 01 & $1.15 \%$ \\
Vocal cord palsy & 01 & $1.15 \%$ \\
Tubercular laryngitis & 01 & $1.15 \%$ \\
Functional aphonia & 87 & $100 \%$ \\
\hline Total & & \\
\hline
\end{tabular}

Most common cause of change of voice is Carcinoma of larynx (37.93 \%) and chronic laryngitis $(22.99 \%)$ in our study. Vocal cord nodules (19.54\%) and vocal cord polyps (8.05 $\%)$ also contributes to change of voice in our study population.

1 case was diagnosed as TB laryngitis and 1 case as functional aphonia.

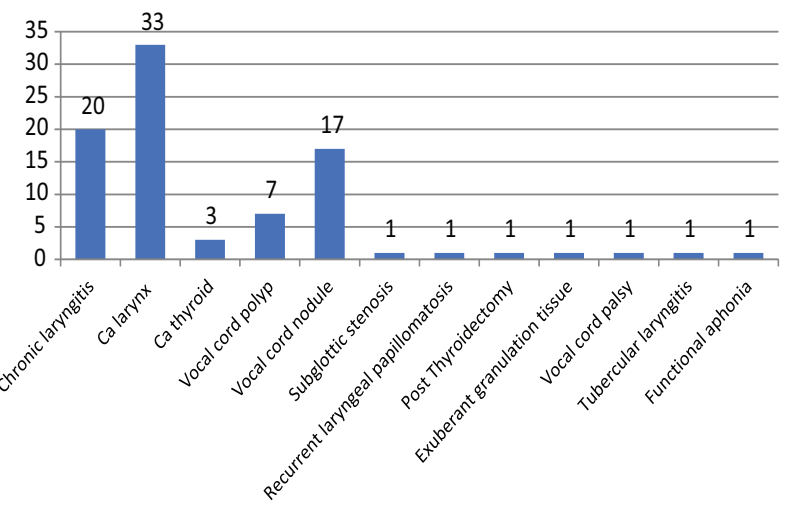

Figure shows number of cases of various causes of change of voice in study population.
Table VII

Duration of change of voice in study population $(n=87)$

\begin{tabular}{lcc}
\hline $\begin{array}{l}\text { Duration of hoarseness } \\
\text { of voice }\end{array}$ & $\begin{array}{l}\text { No of } \\
\text { cases }\end{array}$ & Percentage \\
\hline Within 3 months & 42 & $48.27 \%$ \\
3 to 6 months & 19 & $21.84 \%$ \\
6 to 12 months & 9 & $10.34 \%$ \\
More than 12 months & 17 & $19.54 \%$ \\
\hline Total & 87 & $100 \%$ \\
\hline
\end{tabular}

Patients were suffering from change of voice for a variable period of time. It was recorded in days, weeks, months and years. Duration of change of voice ranged from 2 days to 5 years. Most of the patients were presented within 03 months due to availability of free treatment provision at $\mathrm{DMCH}$. 21.84\% patient presented with hoarseness within 3 to 6 months. 10.34\% presented within 6 to 12 months and 19.54\% presented after 12 months and onwards. Educated persons, professional voice users and students reported early. The poor, illiterate and 
patients with carcinoma larynx reported relatively late and sometimes reported with advanced disease. Patients with carcinoma larynx reported within 4 to 6 months and minimum time taken in case of glottic carcinoma (average 2 months) and maximum of 12 months for civil patient suffering from supraglottic carcinoma.

Table VIII

Distribution of age group according to cause in study population $(n=87)$

\begin{tabular}{l}
\hline Disease / Causes \\
$\begin{array}{c}\text { No of Average age } \\
\text { patients in years }\end{array}$ \\
\hline
\end{tabular}

Chronic laryngitis $\quad 20 \quad 35$

Ca larynx :

- Suraglottic $(n=28)$

- Glottic $(\mathrm{n}=4)$

- Subglottic $(\mathrm{n}=1)$ $33 \quad 52$

Ca thyroid $03 \quad 38$

Vocal cord polyp $07 \quad 35$

Vocal cord nodule $17 \quad 28$

Subglottic stenosis

$01 \quad 36$

Recurrent laryngeal

01

12

papillomatosis

Post Thyroidectomy $01 \quad 42$

Exuberant granulation

01 45

tissue

Vocal cord palsy 01 44

Tubercular laryngitis

01 35

Functional aphonia

Total 01

Most of the patients in our study were suffering from Carcinoma of the larynx. Mostly observed in elderly adult ( $6^{\text {th }}$ decade) and old personnel. Acute and chronic laryngitis in $3^{\text {rd }} \& 4^{\text {th }}$ decade. Vocal cord nodules and vocal cord polyps were common in middle age group. There was 01 case of recurrent laryngeal papilloma in a 12 years old child. 01 case case of functional aphonia of newly married young women was seen.
Table IX

Distribution of sex according to cause in study population $(n=87)$

\begin{tabular}{|c|c|c|}
\hline Disease / Causes & $\begin{array}{c}\text { No of } \\
\text { patients }\end{array}$ & $\begin{array}{c}\text { Male to } \\
\text { female ratio }\end{array}$ \\
\hline Chronic laryngitis & 20 & $3: 2$ \\
\hline $\begin{array}{l}\text { Ca larynx : } \\
\text { - } \quad \text { Suraglottic }(n=28) \\
\text { - } \text { Glottic }(n=4)\end{array}$ & & \\
\hline - Subglottic(n=1) & 33 & Male \\
\hline Ca thyroid & 03 & Female \\
\hline Vocal cord polyp & 07 & $2: 1$ \\
\hline Vocal cord nodule & 17 & $1: 1$ \\
\hline Subglottic stenosis & 01 & Male \\
\hline $\begin{array}{l}\text { Recurrent laryngeal } \\
\text { papillomatosis }\end{array}$ & 01 & Male \\
\hline Post Thyroidectomy & 01 & Female \\
\hline $\begin{array}{l}\text { Exuberant granulation } \\
\text { tissue }\end{array}$ & 01 & Male \\
\hline Vocal cord palsy & 01 & Male \\
\hline Tubercular laryngitis & 01 & Male \\
\hline Functional aphonia & 01 & Female \\
\hline
\end{tabular}

Table X

Histopathological findings after direct laryngoscopic assessment \& biopsy in study population $(n=38)$

\begin{tabular}{lcc}
\hline Disease / Causes & $\begin{array}{c}\text { No of } \\
\text { patients }\end{array}$ & $\begin{array}{c}\text { Percentage } \\
\%\end{array}$ \\
\hline Ca larynx : & & \\
- Suraglottic $(\mathrm{n}=28)$ & & \\
- Glottic $(\mathrm{n}=4)$ & & \\
- Subglottic(n=1) & 33 & $55 \%$ \\
Vocal cord polyp & 07 & $11.67 \%$ \\
Vocal cord nodule & 17 & $28.33 \%$ \\
Recurrent laryngeal & 01 & $1.66 \%$ \\
papillomatosis & & \\
Exuberant granulation & 01 & $1.66 \%$ \\
tissue & & \\
Tubercular laryngitis & 01 & $1.66 \%$ \\
\hline Total & 60 & $100 \%$ \\
\hline
\end{tabular}


Direct laryngoscopy was needed in 60 patients. Carcinoma of larynx were most commonly encountered in 33 cases (55\%). Vocal cord nodule was in 17 cases $(28.33 \%)$, vocal cord polyp were in 07 cases $(11.67 \%)$. Single case of recurrent laryngeal papillomatosis, Exuberant granulation tissue and Tubercular laryngitis was noted.

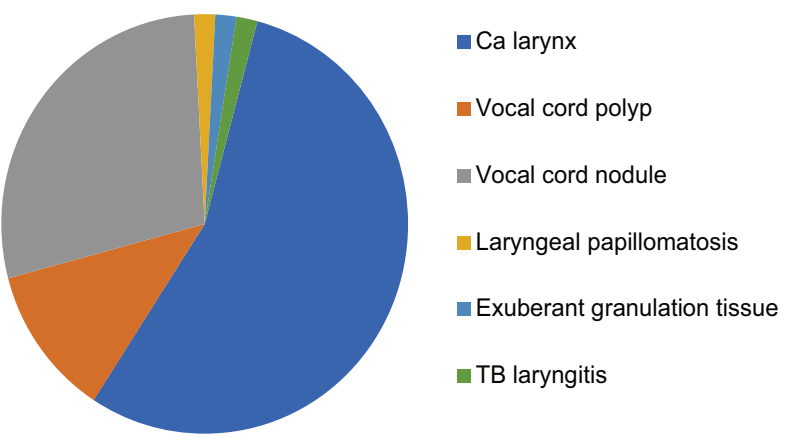

Figure shows percentage of diseases diagnosed by histopathological findings after direct laryngoscopic assessment $\&$ biopsy in study population.

\section{Discussion:}

A total of 87 patients were included in this study. Majority of patients were seen in age group of 31-40 years (28.74\%) and 51-60 years (20.69\%) followed by 3rd decade 21-30 years (14.94\%). Baitha et $\mathrm{al}^{21}$ also found majority of patients $(28.18 \%)$ in the age group of 31 to 40 years. Batra et $\mathrm{al}^{26}$ found largest group comprising $25 \%$ in 31 to 40 years age group. Kumar $\mathrm{H}$ et $\mathrm{al}^{25}$ found $31 \%$ patients in $31-40$ years age group. In our study $56.32 \%$ patients were seen in age group of 21-50 years. This observation slightly differs from Deshmukh ${ }^{23}$, Mehta $\mathrm{AS}^{22}$ and Baitha et $\mathrm{al}^{21}$ with $63.1 \%$, $67.2 \%$ and $61.81 \%$ patients in $21-50$ years age group respectively. So my study result slightly differs with the results of all these studies.

In this study, males were $56(64.37 \%)$ and females were $31(35.63 \%)$, with male predominance and male female ratio of 1.81:1. This coincides with study by Karan Sharma et $\mathrm{al}^{18}$, Parikh $\mathrm{N}^{19}$, Ahmad et $\mathrm{al}^{20}$, Baitha $\mathrm{S}$ et $\mathrm{al}^{21}$, Mehta $\mathrm{AS}^{22}$, Deshmukh ${ }^{23}$, Banjara $\mathrm{H}$ et $\mathrm{al}^{24}$, Ku-mar $\mathrm{H}$ et $\mathrm{all}^{25}$, Batra et $\mathrm{al}^{26}$ and Behera et $\mathrm{al}^{27}$. All these studies were showing male predominance and male female ratio between 1.65:1 to $2: 1$.

Koufman and Isaacson evolved a classification of vocal professionals based on their voice use and risk ${ }^{17}$.

1. Level I (elite vocal performers): Included sophisticated voice users like the singers and actors, where even a slight vocal difficulty causes serious consequences to them and their careers.

2. Level II (professional voice users): For whom even moderate vocal difficulty would hamper adequate job performance. Clergymen, lecturers, teachers, politicians, public speakers and telephone operators would classify in this level of voice users.

3. Level III (non -vocal professionals): It includes teachers and lawyers. They can perform their jobs with slight or moderate voice problems; only severe dysphonia endangers adequate job performance.

4. Level IV (non-vocal no- professionals): It includes labourers, homemakers, businessmen and clerks. These are the persons who are not impeded from doing their work when they experience any kind of dysphonia.

In this study, according to this classification, we found $2.30 \%$ elite vocal performers, $9.19 \%$ professional voice users, $1.15 \%$ non-vocal professionals and $87.35 \%$ non-vocal nonprofessionals. Banjara $\mathrm{H}$ et $\mathrm{al}^{24}$ found $1.59 \%$ elite vocal perfomers, $3.59 \%$ professional voice users, $9.56 \%$ non-vocal professionals and $85.26 \%$ non-vocal non-professionals. So, our

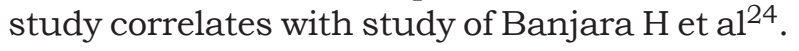

In this study, smoking was the most common predisposing factor found in $43.68 \%$ patients. Our study correlates with study of Banjara $\mathrm{H}$ et $\mathrm{al}^{24}$ and Behera et $\mathrm{al}^{27}$ with $43 \%$ and $43.75 \%$ patients were associated with smoking. Chronic mucosal irritation by heavy smoking, excessive intake of alcohol and tobacco chewing in Asian countries play significant role in etiology of hoarseness. It was observed that in India and other developing countries the prevailing lower economic status, poor nutrition and general health, vocal habits, smoking and drinking 
habits, unhealthy environment, and different social customs influence the incidence of hoarseness ${ }^{19}$.

In this study, change in voice was found in all patients $(100 \%)$. Other symptoms were vocal fatigue, cough, sore throat, fever, foreign body sensation, vocal fatigue, dysphagia, weight loss, dyspnoea, neck swelling, respiratory distress etc.

Mehta $\mathrm{AS}^{22}$, Parikh $\mathrm{N}^{19}$ and Baitha et $\mathrm{al}^{21}$ also found change in voice in all $100 \%$ patients. Other symptoms were also comparable with our study.

Vocal abuse was found in $36.78 \%$ patients. It correlates with study of Banjara $\mathrm{H}$ et $\mathrm{al}^{24}$, Behera et $\mathrm{al}^{27}$ with $31 \%$ and $35 \%$ patients with vocal abuse respectively. In our study, vocal abuse was main predisposing factor in vocal nodules, vocal cysts and vocal cord polyps. Smoking and tobacco chewing together constitute major pre-disposing factor in malignancy, acute and chronic laryngitis.

Duration of change of voice ranged from 7 days to more than 3 years. Most of presenting complaints $48.27 \%$ were seen within 3 months, $21.84 \%$ within 3 to 6 months, $10.34 \%$ within 6 to 12 months and $19.54 \%$ complaints were of more than 1 year duration. Batra et $\mathrm{al}^{26}$ found $59 \%$ patients within first five months of appearance of symptoms and $86 \%$ of patients were found to present within first year of appearance of symptoms. Baitha et $\mathrm{al}^{21}$ noted duration range from 1 day to 5 years and $50 \%$ patients had duration of voice change in months. Chopra and Kapoor ${ }^{28}$ found $68.65 \%$ patients with duration of change of voice of less than one year. Banjara $\mathrm{H}$ et $\mathrm{al}^{24}$ found $20.72 \%$ complaints were of more than 1 year duration. In our study, $19.54 \%$ complaints were of more than 1 year duration. So, our study correlates with all these studies.

In this study carcinoma larynx (37.93\%) was found the most common etiology of change of voice. Other cause were chronic laryngitis (20.99\%), vocal cord nodule (19.54\%) followed by vocal cord polyp $(8.05 \%)$, carcinoma thyroid $(3.45 \%)$, vocal cord palsy $(1.15 \%)$, functional $(1.15 \%)$, TB laryngitis $(1.15 \%)$, Subglottic stenosis $(1.15 \%)$ and Recurrent laryngeal papillomatosis (1.15\%) etc.

In this study, carcinoma larynx was found as most common cause of change of voice in $37.93 \%$ patients. My study result differs from the study of Banjara $\mathrm{H}$ et $\mathrm{al}^{24}$, Baitha et $\mathrm{al}^{21}$, Kumar $\mathrm{H}$ et $\mathrm{al}^{25}$, Parikh et $\mathrm{al}^{19}$, Saeed $\mathrm{M}$ and Mian $\mathrm{FA}^{30}$ with carcinoma larynx as a cause of change of voice in $9.56 \%, 14.54 \%, 15 \%, 12 \%$ and $11 \%$ respectively.

Chronic laryngitis was one of the leading cause of change of voice $(20.99 \%)$. Behera et $\mathrm{al}^{27}$ found chronic laryngitis as the most common cause and found in $25 \%$ cases. Our study also correlates with study of Baitha et $\mathrm{al}^{21}$ with $21.81 \%$ cases with chronic laryngitis. Chronic laryngitis was associated with tobacco in $54.05 \%$ patients and laryngopharyngeal reflux in $45.95 \%$ patients. This is comparable to the study by Koufmann ${ }^{17}$ in which laryngopharyngeal reflux was associated with $40 \%$ cases of chronic laryngitis.

Vocal cord nodules were found in 19.54\% patients. Among them around $60 \%$ was bilateral. Baitha et $\mathrm{al}^{21}$ and Mehta et $\mathrm{al}^{22}$ also found bilateral vocal nodules in most of the patients. Kumar $\mathrm{H}$ et $\mathrm{al}^{25}$ found vocal nodules in $18 \%$ cases. Behera et $\mathrm{al}^{27}$ found vocal nodules in $15 \%$ cases. Banjara $\mathrm{H}$ et $\mathrm{al}^{24}$ found vocal nodules in $11.95 \%$ cases. Baitha et $\mathrm{al}^{21}$ found vocal nodules in $12.72 \%$ cases.

Vocal cord polyps were found in $8.05 \%$ patients. These result differs with study of Banjara $\mathrm{H}$ et $\mathrm{al}^{24}$, Baitha et $\mathrm{al}^{21}$ with $3.59 \%$ and $4.54 \%$ cases respectively.

Direct laryngoscopy was needed in 60 patients. Carcinoma of larynx was most commonly encountered in 33 cases (55\%). Vocal cord nodule was in 17 cases $(28.33 \%)$, vocal cord polyp were in 07 cases $(11.67 \%)$. Single case of recurrent laryngeal papillomatosis, Exuberant granulation tissue and Tubercular laryngitis was noted.

\section{Conclusion:}

Change of voice is just a symptom with a very diverse etiology. The etiological data varies in different geographical location and from one center to other, so every case should be carefully 
and thoroughly evaluated to know the diagnosis and underlying pathology for early and prompt management. A sequential history, physical examination and appropriate investigations can lead to appropriate diagnosis.

A patient presenting with change of voice in ENT OPD may have anything from a viral infection that just needs voice rest to an overtly malignant lesion, the treatment for which may be aggressive. Therefore early diagnosis of the underlying cause becomes all the more important in every case. The earlier a malignancy is identified, the better the prognosis. It is easier to get rid of abusive habits that have not had a lengthy period to develop. So early diagnosis and treatment may shorten the time period for which the patient remains dysfunctional.

Cessation of smoking and usage of other tobacco preparations and alcohol can lead to significant reduction in the incidence of laryngitis and carcinoma of larynx and in turn will reduce the burden of voice change.

Avoidance of vocal abuse can also lead to decrease the burden of change of voice. So, change of voice is an alarming symptom and it should not be ignored and thorough investigations should be done to make a final diagnosis.

\section{References}

1. Loyn SB. Doctor my voice seems husky. Auster Fam Physician. 1994;23:2111.

2. Arnold E Aronson, Diane M. Clinical voice disorders. 4th edition.1954;305.

3. Chevalier Jackson. Diseases of ear, nose and throat, 2nd edition. 1959;576.

4. Waleem SU, Ali S, Ishaque M. Etiology of hoarseness: A study of 100 cases. Pak J Otolaryngol.2005;21:3941.

5. Dettelbach M, Eibling DE, Johnson JT. Hoarseness from viral laryngitis to glottis cancer. Postgrad Med.1994;95:143.

6. Evans JM, Schucany WG; Hoarseness and cough in a 67-year-old woman. Proc (Bayl Univ Med Cent). 2004 Oct;17(4):468-9.

7. Bossingham DH, Simpson FG; Acute laryngeal obstruction in rheumatoid arthritis. BMJ. $1996 \mathrm{Feb}$ 3;312(7026):295-6.
8. Ulis JM, Yanagisawa E; What's new in differential diagnosis and treatment of hoarseness? Curr Opin Otolaryngol Head Neck Surg. 2009 Jun; 17(3): 209-15

9. Hamdan AL, Sarieddine D; Laryngeal manifestations of rheumatoid arthritis. Autoimmune Dis. 2013;2013:103081.

10. Carding P; Voice pathology in the United Kingdom. BMJ. 2003 Sep 6;327(7414):514-5.

11. Syed I, Daniels E, Bleach NR; Hoarse voice in adults: an evidence-based approach to the 12 minute consultation. ClinOtolaryngol. 2009 Feb;34(1):54-8.

12. Ruiz R, Jeswani S, Andrews K, et al; Hoarseness and laryngopharyngeal reflux: a survey of primary care physician practice patterns. JAMA Otolaryngol Head Neck Surg. 2014 Mar;140(3):192-6.

13. Lim S, Sau P, Cooper L, et al; The incidence of premalignant and malignant disease in Reinke's edema. Otolaryngol Head Neck Surg. 2014 Mar;150(3):434-6.

14. Printza A, Triaridis S, Themelis C, et al; Stroboscopy for benign laryngeal pathology in evidence based health care.Hippokratia. 2012 Oct;16(4):324-8.

15. DeConde AS, Long JL, Armin BB, et al ; Functional reinnervation of vocal folds after selective laryngeal adductor denervation-reinnervation surgery for spasmodic dysphonia. J Voice. 2012 Sep;26(5): 602-3.

16. Judd O, Colvin IB. Hoarse voice. BMJ 2010; 340: c522.

17. Koufman J, Isaacson G. The spectrum of vocal dysfunction. The Otolaryngologic clinics of North America: Voice disorders. Philadelphia: WB Saunders. 1991;47.

18. Sharma K, Sachdeva R, Duggal K, Kahlon SK. Direct laryngoscopic observations in pro-gressive hoarseness of voice. Indian J Otolaryn-gol Head Neck Surg.2006;58(4):364-6

19. Nimish Parikh. Aetiological study of 100 cases of hoarseness of voice. Indian J Otolaryn-gol Head Neck Surg. June 91;43(2):71-3.

20. Ahmad Z, Matiullah S, Memon M, Marfani MS. Aclinicopathological study of laryngeal ma-lignancies: an institutional experience. J Liaquat Uni Med Health Sci.2009;8:214-8.

21. Sambu Baitha, Raizada RM, Kennedy Singh AK, Puttewar MP, Chaturvedi VN. Clinical profile of hoarseness of voice. Indian J Oto-laryngol Head Neck Surg.2002;54(1):14-8.

22. Mehta AS. An etiological study of hoarseness of voice. A thesis submitted for mas-ter of surgery (Otorhinolaryngology), Gu-jarat University, 1985. 
23. Deshmukh. Clinical study of hoarseness of voice. A thesis submitted for master of surgery (Otorhinolaryngology), Gujarat University, 1976.

24. Banjara H, Mungutwar V, Singh D, Gupta A. Hoarseness of voice: A retrospective study of 251 cases. International J Phonosurgery and Laryngology. 2011;1(1):21-7.

25. Kumar H, Seth S, Kishore D. Aetiologi-cal study of 100 cases of hoarseness of voice. Otorhinolaryngology and Head \& Neck Surgery.2011;8(1):23.

26. Kadambari Batra, Gul Motwani, PC Sagar. Functional voice disorders and their occurrence in 100 patients of hoarseness as seen on fibreoptic laryngoscopy. Indian J Otolaryngol Head Neck Surg.2004;56(2):91-95.

27. Behera SK, Mishra SK, Rafiya KK, Mishra SK, Patsani M. Clinicopathological study of hoarseness of voice. Odisa J Oto-rhinolaryngol Head Neck Surg.2012; 6(1):23-6.

28. Chopra H, Kapoor M. Study of benign glottis lesions undergoing microlaryngeal surgery. Indian $\mathrm{J}$ Otolaryngol Head Neck Surg.1997;49(3):276-9.

29. Koufman JA, Belafsky PC, Bach KK et al. Prevalence of esophagitis in patients with $\mathrm{pH}$-documented laryngopharyngeal reflux. Laryngoscope.2002; 112: 1606-9.

30. Saeed M, Mian FA. Hoarseness of voice. Professional Med J.2006;13(4):504 